\title{
Assessing the Environmental Performance of a New Biotechnological Sensor for Air Quality Based on Devitalised Moss Clone
}

\author{
Carolina Alfonsín ${ }^{1}$, Paula Pérez-López ${ }^{1}$, Ana Isabel Rey-Asensio ${ }^{2}$, Carlos \\ Carballeira $^{3}$, Gumersindo Feijoo ${ }^{1}$, and Maria Teresa Moreira ${ }^{1}$ \\ ${ }^{I}$ Department of Chemical Engineering, Institute of Technology, University of Santiago de Compostela, Santiago \\ de Compostela, Galicia, Spain \\ ${ }^{2}$ BIOVIA Consultor Ambiental, Edificio Emprendia, Campus Vida, Santiago de Compostela, Galicia, Spain \\ ${ }^{3}$ Área de Ecología, Facultad de Biología, University of Santiago de Compostela, Santiago de Compostela, \\ Galicia, Spain
}

Corresponding author:

Carolina Alfonsin, Department of Chemical Engineering, Institute of Technology, University of Santiago de Compostela, 15782 Santiago de Compostela, Galicia, Spain

E-mail: carolina.alfonsin@rai.usc.es

(received in March 2014; accepted in March 2015)

In recent years, mosses have been suggested as feasible biomonitors for the control of air quality. The most suitable type of biosensor consists of moss transplants that can be either harvested from unpolluted natural habitats or cultivated in photobioreactors. The production and devitalisation of moss was assessed with the aim of identifying the stages of the process with potential environmental impacts. The use of energy, especially associated with refrigeration in the cultivation stage, was the main factor contributing to the environmental impacts considered, ranging from $85 \%$ of the impact in marine eutrophication up to $95 \%$ for the rest of categories. Results were compared with previous studies dealing with algae production in photobioreactors, in which the electricity use for lighting also constituted a major hotspot. Scenarios based on reduced energy demand, and implementing alternative sources were proposed and showed better environmental profiles than the baseline scenario. Particularly, the use of photovoltaic energy could reduce the impacts by $50 \%$ in the analysed categories, except for terrestrial ecotoxicity, with significantly lower improvement ratios if photovoltaic energy was partially combined with conventional energy. The option of optimising the refrigeration system also provided significant reductions, ranking as the best alternative when terrestrial ecotoxicity was assessed.

Keywords: air quality, environmental assessment, life cycle assessment (LCA), moss clone, photobioreactor.

\section{Introduction}

Atmospheric pollution has increasingly shown adverse effects on both, human health and environment (Kampa \& Castanas, 2008). Europe has become aware of the problem and European countries deal with atmospheric pollution by assessing, monitoring and controlling air quality (Garrido, Jiménez-Guerrero, \& Ratola, 2014; Vallero, 2014). Recently, compounds such as polycyclic aromatic hydrocarbons (PAHs) and trace metals have emerged as one of the most important issues regarding air quality. For this reason, their monitoring is recommended by EU legislation (European Commission (EC), 2004). Typically, conventional techniques such as bulk deposition collectors for particles and gaseous samplers have been applied for air quality measurements. 
Nevertheless, automatic devices at monitoring stations show technical difficulties and high economical costs when micro-contaminants are measured. The use of mosses as biomonitors of atmospheric quality has arisen to overcome the limitations associated with traditional techniques (Rühling \& Tyler, 1968; Gerdol, Marchesini, Iacumin, \& Brancaleoni, 2014; Vuković et al., 2014; Wu, Wang, \& Zhou, 2014). The main advantage of using mosses as biomonitors is their high efficiency to accumulate a wide range of airborne pollutants, including trace metals (Schröder et al., 2008; Fabure et al., 2010) and organic compounds (Harmens, Foan, Simon, \& Mills, 2013).

The development of biological monitoring methods based on mosses can be classified into passive biomonitoring, when endogenous species are used (Ferreira, Santos, Souza, Júnior, \& Alves, 2012), and active biomonitoring, based on placing biosensor transplants into the area under assessment. This alternative offers a number of advantages over the former option (Aboal, Couto, Fernández, \& Carballeira, 2006; Ares et al., 2012, Vuković et al., 2014). Moss bags consist of external structures containing moss inside and they are the most common system of active biomonitoring due to their reliable results, simplicity and cost effectiveness (Tretiach et al., 2007; Cao et al., 2009). The moss used in active biomonitoring can be either harvested from unpolluted natural habitats and cleaned before its use or alternatively, it can be cultured in photobioreactors. Photobioreactors allow cultivating moss from an isolated moss clone and producing a standard culture (Hohe \& Reski, 2002). The process of moss cultivation in photobioreactors starts by adding the inoculum obtained in agitated flasks. Once the reactor is inoculated, biomass growth with high values of yield and productivity is possible with a simple medium of inorganic salts, along with illumination and carbon dioxide as energy and carbon sources (Reski \& Abel, 1985). It is a simple process that does not need the addition of more complex additives other than nutrients for the culture medium.

In general, moss bioreactors are designed at laboratory scale as stirred glass vessels or modular glass tubular reactors. Although the former have been widely used for submerged cultures (Decker \& Reski, 2004; 2007), limited illumination is inherent to this reactor configuration. As a consequence, tubular reactors are highly recommended for scaling up (Lucumi, Posten, \& Pons, 2005; Lucumi \& Posten, 2006; Decker \& Reski, 2007; Perner-Nochta, Lucumi, \& Posten, 2007). Optimal conditions for moss cultivation in photobioreactors comprising $\mathrm{pH}$, nutrients, external illumination, stirring speed, aeration and density of inoculation have been established for the species Physcomitrella patens (Hohe \& Reski, 2002; Schween, Hohe, Koprivova, \& Reski, 2003; Hohe \& Reski, 2005). Glass photobioreactors ranging from 10 to 301 with external illumination, e.g. normal fluorescent tubes (Decker \& Reski, 2004) or white light metal halide lamps (Lucumi \& Posten, 2006), have been successfully applied for moss cultivation-

Regarding the cultivation of moss in bioreactors for air quality control, Pseudoscleropodium purum and Ceratodon purpureus have been cultivated with the objective of accumulating metal trace elements (Fabure et al., 2010) and Sphagnum palustre has been recommended as the most suitable species to capture and accumulate contaminants (Ares et al., 2012).

Recent studies highlighted the advantages of using devitalised moss for active biomonitoring (Hohe \& Reski, 2005): the avoidance of moss growth during exposure time,-the possibility to provide results that are not affected by the metabolic activity (Fernández et al. 2009, Adamo et al. 2011) and the replicability of the obtained results. Oven-drying procedure was found to be the most adequate alternative to devitalise moss since this option maintains moss structure after drying (Lucumi et al. 2005; Fernández, Ares, Rey-Asensio, Carballeira, \& Aboal, 2009).

With the objective of evaluating all the environmental impacts associated with products, processes and services, life cycle assessment (LCA) has been considered as the most suitable methodology (ISO 2006). Biomass cultivation in photobioreactors has only been assessed for algae while there is no previous study for moss photobioreactors. The main outcomes of these studies revealed the importance of the photobioreactor operation in the global environmental impact (PérezLópez et al., 2014b; Pérez-López et al., 2014c; PérezLópez et al., 2014d).

This research paper assesses the production process of the moss species Sphagnum palustre in a photobioreactor as well as its further devitalisation. The process consisted of several steps including preparation of the culture medium, cultivation of the inoculum, production of moss in a 151 photobioreactor and finally, the stages of washing and devitalisation of the moss. Additionally, cleaning with water and soap and sterilisation of the reactor were included into the analysis. The outcomes will identify the stages with the largest environmental impacts and different options will be proposed to improve the environmental performance of moss cultivation.

\section{Materials and methods \\ 2.1 Goal and scope definition}

This paper aims at performing the environmental assessment of the production process of the moss Sphagnum palustre in a photobioreactor at labaratory scale. The objective of the study was to determine the most relevant stages from an environmental point of view. The process was evaluated according to a cradle-to-gate perspective, including from the production processes, such as chemicals and energy production, to the final product: the moss clone. The functional unit was 
defined as $109 \mathrm{~g}$ of dry moss, which corresponded to 1 batch of production.

\subsection{Overview of the production system}

The system for the production of devitalised moss was split in five subsystems (Figure 1) according to the different procedures carried out during the process: Subsystem 1, reactor cleaning; Subsystem 2, preparation of the culture medium; Subsystem 3, cultivation of the inoculum; Subsystem 4, cultivation of the moss and Subsystem 5, washing and devitalisation of the moss.

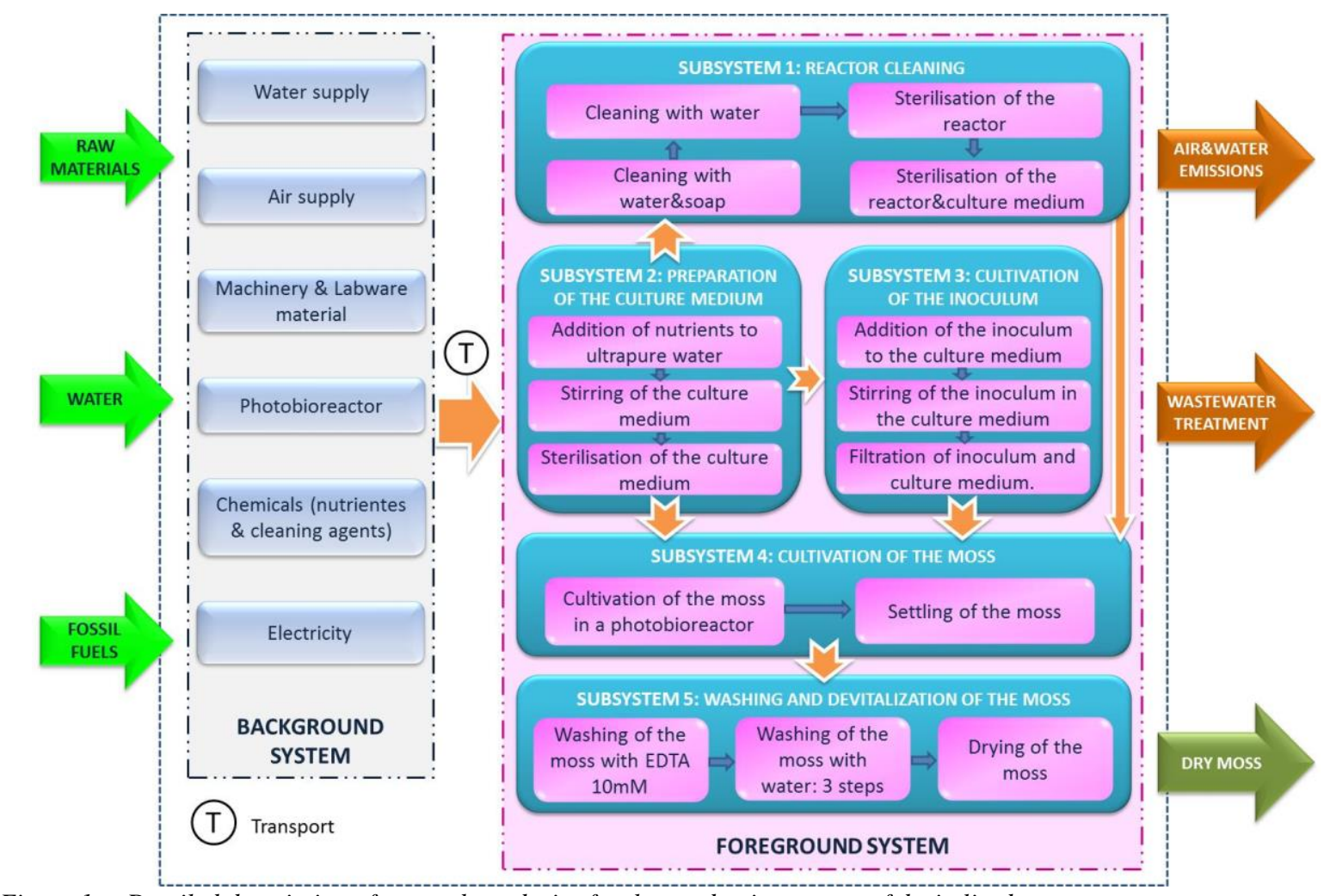

Figure 1. Detailed description of system boundaries for the production system of devitalised moss.

Subsystem 1. Reactor cleaning: The reactor was cleaned with 751 of water and liquid soap, followed by a washing step with 51 of distilled water. Thereafter, it was autoclaved twice for $20 \mathrm{~min}$ (1 atm, $\left.121^{\circ} \mathrm{C}\right)$; in the second step, filled with 21 of culture medium.

Subsystem 2. Preparation of the culture medium: The composition of the culture medium comprised the following chemicals for a total volume of $13 \mathrm{l}: 3.25 \mathrm{~g}$ $\mathrm{KH}_{2} \mathrm{PO}_{4}, 3.25 \mathrm{~g} \mathrm{KCl}, 3.25 \mathrm{~g} \mathrm{MgSO}_{4} \cdot 7 \mathrm{H}_{2} \mathrm{O}, 13.00 \mathrm{~g}$ $\mathrm{Ca}\left(\mathrm{NO}_{3}\right)_{2} \cdot 4 \mathrm{H}_{2} \mathrm{O}, \quad 0.16 \mathrm{~g} \quad \mathrm{FeSO}_{4} \cdot 7 \mathrm{H}_{2} \mathrm{O}, \quad 4.0210^{-}$ ${ }^{2} \mathrm{~g} \mathrm{H}_{3} \mathrm{BO}_{3}, \quad 0.11 \mathrm{~g} \quad \mathrm{MnSO}_{4} \cdot \mathrm{H}_{2} \mathrm{O}, \quad 5.4010^{-3} \mathrm{~g} \quad \mathrm{KI}$, $5.60 \cdot 10^{-2} \mathrm{~g} \quad \mathrm{ZnSO}_{4} \cdot 7 \mathrm{H}_{2} \mathrm{O}, \quad 1.57 \cdot 10^{-3} \mathrm{~g}$ $\mathrm{Na}_{2} \mathrm{MoO}_{4} \cdot 2 \mathrm{H}_{2} \mathrm{O}, 1.63 \cdot 10^{-4} \mathrm{~g} \mathrm{CuSO}_{4} \cdot 5 \mathrm{H}_{2} \mathrm{O}, 1.90 \cdot 10^{-}$ ${ }^{4} \mathrm{~g} \quad \mathrm{Co}\left(\mathrm{NO}_{3}\right)_{2} \cdot 6 \mathrm{H}_{2} \mathrm{O}, \quad 1.30 \mathrm{~g} \quad \mathrm{NH}_{4} \mathrm{NO}_{3}, \quad 296.66 \mathrm{~g}$ $\mathrm{C}_{12} \mathrm{H}_{22} \mathrm{O}_{11}$ and $2.67 \cdot 10^{-3} \mathrm{ml} \mathrm{HCl}$. A value of $\mathrm{pH} 4$ was adjusted by adding $\mathrm{HCl}(445 \mu \mathrm{l}, 0.5 \mathrm{~N})$. The next step was the sterilisation of culture medium (131) in autoclave for $20 \mathrm{~min}\left(1 \mathrm{~atm}, 121^{\circ} \mathrm{C}\right)$, to be used as follows: 21 for Subsystem 1, 11 for inoculum cultivation in Subsystem 3 and the remaining 101 that were directly used for the start-up of the reactor in Subsystem 4.

Subsystem 3. Cultivation of the inoculum: Small-scale moss cultivation was performed for inoculum growth. For this purpose, 5 flasks of $500 \mathrm{ml}$ were inoculated with $0.36 \mathrm{~g}$ dry weight (dw), equivalent to $18 \mathrm{~g}$ fresh weight (fw), per flask under constant stirring and artificial illumination with a 16:8 regime $(36 \mathrm{~W})$ for 21 days. Once the required density was achieved: $0.8 \mathrm{~g} \mathrm{dw}(40 \mathrm{~g} \mathrm{fw})$ per flask, the culture medium was filtered and the moss was ready to inoculate the photobioreactor.

Subsystem 4. Cultivation of the moss: The 151 glass photobioreactor (Figure 2) previously autoclaved with 21 of culture medium (in Subsystem 1) was inoculated with $4 \mathrm{~g} \mathrm{dw}$ (200 g fw) of inoculum from Subsystem 3 in 101 of culture medium prepared in Subsystem 2. The photobioreactor was illuminated with continuous light at $210 \mu \mathrm{mol} \mathrm{m} \mathrm{m}^{-2} \mathrm{~s}^{-1}$ with $14 \mathrm{LED}$ tubes of $8 \mathrm{~W}$ each. The moss was continuously aerated with $21 \mathrm{~min}^{-1}$ of air with $2 \% \mathrm{CO}_{2}$ and agitated at $500 \mathrm{rpm}$ for $1 \mathrm{~min}$ every day. Temperature was set at $25^{\circ} \mathrm{C}$ using a refrigerated bath. Water was kept at $10^{\circ} \mathrm{C}$ inside the refrigerated bath, which was used not only to maintain the culture medium at $25^{\circ} \mathrm{C}$ but also for the condenser to avoid evaporation of the culture medium. In general, $\mathrm{pH}$ was naturally kept in a range between 3 and 4 without the addition of chemicals, which favoured moss growth.

After 27 days of operation, the moss production achieved a value of $3.9 \mathrm{~g} \mathrm{dw}^{-1} \mathrm{day}^{-1}$ (Beike et al. 2014). The culture medium was poured off to collect moss: $109 \mathrm{~g} \mathrm{dw}(1,400 \mathrm{~g} \mathrm{fw})$ with $100 \%$ moisture. 


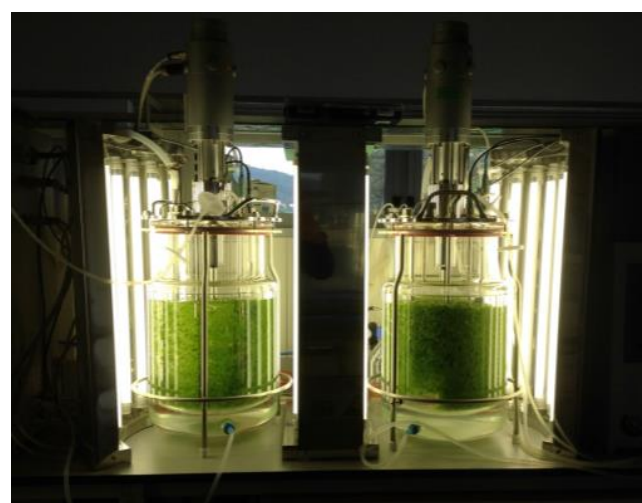

Figure 2. Stirred glass tanks operated for S. palustre cultivation after 1 week (left) and 3 weeks (right) from inoculation. Photographs courtesy of BioVia Consultor Ambiental.

Subsystem 5. Washing and devitalisation of the moss: The moss was washed for 20 min with 8.71 of $10 \mathrm{mM}$ ethylenediaminetetraacetic acid (EDTA), following a ratio of 11 of EDTA per $12.5 \mathrm{~g} \mathrm{dw}$. Thereafter, 3 consecutive washes of 20 min with 10.931 of distilled water in each step were carried out, according to a ratio of $1 \mathrm{l}$ of distilled water per $10 \mathrm{~g}$ $\mathrm{dw}$. The moss was washed with the objective of removing ions attached to the tissue, which would hinder moss accumulation capacity. Finally, devitalisation was performed in an oven, with a temperature slope rise every $8 \mathrm{~h}: 8 \mathrm{~h}$ at $50^{\circ} \mathrm{C}, 8 \mathrm{~h}$ at $80^{\circ} \mathrm{C}$ and $8 \mathrm{~h}$ at $100{ }^{\circ} \mathrm{C}$, for a final weight of $109 \mathrm{~g}$ of dry biomass.

\subsection{Life cycle inventory (LCI)}

The LCI data for the foreground system were obtained from on-site measurements whereas background data were taken from the Ecoinvent database (Ecoinvent, 2007) (Table 1). The latter includes the production of chemicals such as nutrients and EDTA as well as soap added to clean the reactor, water and air supply, energy used, equipment and laboratory ware such as glass beakers and test tubes, transport and waste treatment scenarios. The inventory for energy production was modified according to data from the electricity production/importation system for Spain in 2013 (RedElectrica, 2013). The electricity transmission network, emissions of sulphur hexafluoride to air as well as losses during the low voltage transmission and transformation from high to low voltage were considered (Dones et al., 2007).

Table 1. Summary of data sources considered in this study.

\begin{tabular}{|c|c|c|}
\hline \multicolumn{2}{|c|}{ Inventory inputs } & Data sources \\
\hline Energy & Electricity (Spanish profile) & Ecoinvent database (Dones et al., 2007) \\
\hline \multirow[t]{6}{*}{ Materials } & Polypropylene & Ecoinvent database (Hischier, 2007) \\
\hline & White glass & \\
\hline & Amber glass & \\
\hline & Steel & Ecoinvent database (Steiner \& Frischknecht, 2007) \\
\hline & Aluminium & \\
\hline & Parafilm & Ecoinvent database (Althaus et al., 2007) \\
\hline \multirow[t]{16}{*}{ Chemicals } & KH2PO4 & Ecoinvent database (Althaus et al., 2007) \\
\hline & $\mathrm{KCl}$ & \\
\hline & $\mathrm{MgSO} 4 \cdot 7 \mathrm{H} 2 \mathrm{O}$ & \\
\hline & $\mathrm{Ca}(\mathrm{NO} 3) 2 \cdot 4 \mathrm{H} 2 \mathrm{O}$ & \\
\hline & $\mathrm{FeSO} 4 \cdot 7 \mathrm{H} 2 \mathrm{O}$ & \\
\hline & $\mathrm{H} 3 \mathrm{BO} 3$ & \\
\hline & $\mathrm{MnSO} 4 \cdot \mathrm{H} 2 \mathrm{O}$ & \\
\hline & KI & \\
\hline & $\mathrm{ZnSO} 4 \cdot 7 \mathrm{H} 2 \mathrm{O}$ & \\
\hline & $\mathrm{Na} 2 \mathrm{MoO} 4 \cdot 2 \mathrm{H} 2 \mathrm{O}$ & \\
\hline & $\mathrm{CuSO} 4 \cdot 5 \mathrm{H} 2 \mathrm{O}$ & \\
\hline & $\mathrm{Co}(\mathrm{NO} 3) 2 \cdot 6 \mathrm{H} 2 \mathrm{O}$ & \\
\hline & NH4NO3 & \\
\hline & $\mathrm{C} 12 \mathrm{H} 22 \mathrm{O} 11$ & \\
\hline & $\mathrm{HCl}$ & \\
\hline & EDTA & \\
\hline Cleaning agent & Soap & Ecoinvent database (Zah \& R., 2007) \\
\hline Water & Tap water & Ecoinvent database (Althaus et al., 2007) \\
\hline Transport & Lorry, 16-32 t, EURO 4 & Ecoinvent database (Spielmann, Bauer, Dones, \& Tuchschmid, 2007) \\
\hline Water treatment & WWTP & Ecoinvent database (Doka, 2007) \\
\hline
\end{tabular}


The global LCI of the production process is shown in Table 2. All nutrients used to prepare the culture medium were inventoried and compounds that were not included in the Ecoinvent database were considered as chemicals with comparable production processes. The average transport distance of $20 \mathrm{~km}$ was assumed for the transportation of nutrients from the manufacturing industry to the considered process location. The culture medium poured off in Subsystems 3 and 4 was discharged to the sewage system for its further treatment in a wastewater treatment plant (WWTP). The same scenario was assumed for water and soap used as cleaning agents in Subsystem 1. On the contrary, the direct discharge to aquatic environments was assumed for EDTA used in Subsystem 5 based on the negligible removal found for this compound in conventional WWTPs (Clara et al., 2012). Regarding air emissions, only $5.5 \%$ of the $\mathrm{CO}_{2}$ supplied to the system was used by the moss and the excess of $\mathrm{CO}_{2}$ was released to the atmosphere.

Table 2. Global inventory for the production of moss clone in a $15 \mathrm{l}$ stirred glass photobioreactor (Functional unit: $109 \mathrm{~g}$ of moss).

\begin{tabular}{|c|c|c|c|}
\hline \multicolumn{4}{|c|}{ Inputs from nature } \\
\hline \multicolumn{2}{|c|}{ Materials } & & \\
\hline \multicolumn{2}{|c|}{ Subsystem 3. Cultivation of the inoculum } & & \\
\hline Moss & $1.80 \mathrm{~g}$ & & \\
\hline \multicolumn{4}{|c|}{ Inputs from technosphere } \\
\hline \multicolumn{2}{|c|}{ Materials } & \multicolumn{2}{|c|}{ Materials } \\
\hline \multicolumn{2}{|c|}{ Subsystem 1. Reactor cleaning } & \multicolumn{2}{|c|}{ Subsystem 4. Cultivation of the moss } \\
\hline Potable water & 75.001 & Compressed air (2\% CO2) & $77.76 \mathrm{~m} 3$ \\
\hline Distilled water & 5.001 & Photobioreactor, glass & $103.56 \mathrm{~g}$ \\
\hline Soap & $2.00 \cdot 10-2 \mathrm{ml}$ & Laboratory plastic ware & $17.28 \mathrm{~g}$ \\
\hline \multicolumn{2}{|c|}{ Subsystem 2. Preparation of the culture medium } & Stainless steel & $2.47 \mathrm{~g}$ \\
\hline Ultrapure water & 131 & Photobioreactor, stainless steel & $103.56 \mathrm{~g}$ \\
\hline KH2PO4 & $3.25 \mathrm{~g}$ & Steel & $59.18 \mathrm{~g}$ \\
\hline $\mathrm{KCl}$ & $3.25 \mathrm{~g}$ & Silicone & $176.45 \mathrm{~g}$ \\
\hline $\mathrm{MgSO} 4 \cdot 7 \mathrm{H} 2 \mathrm{O}$ & $3.25 \mathrm{~g}$ & \multicolumn{2}{|c|}{ Subsystem 5. Washing and devitalisation of the moss } \\
\hline $\mathrm{Ca}(\mathrm{NO} 3) 2 \cdot 4 \mathrm{H} 2 \mathrm{O}$ & $13.00 \mathrm{~g}$ & Ultrapure water & $41.53 \mathrm{~L}$ \\
\hline $\mathrm{FeSO} 4 \cdot 7 \mathrm{H} 2 \mathrm{O}$ & $0.16 \mathrm{~g}$ & EDTA & $32.55 \mathrm{~g}$ \\
\hline $\mathrm{H} 3 \mathrm{BO} 3$ & $4.02 \cdot 10-2 \mathrm{~g}$ & & \\
\hline $\mathrm{MnSO} 4 \cdot \mathrm{H} 2 \mathrm{O}$ & $0.11 \mathrm{~g}$ & \multicolumn{2}{|c|}{ Electricity } \\
\hline KI & $5.40 \cdot 10-3 \mathrm{~g}$ & \multicolumn{2}{|c|}{ Subsystem 1. Reactor cleaning } \\
\hline $\mathrm{ZnSO} 4 \cdot 7 \mathrm{H} 2 \mathrm{O}$ & $5.60 \cdot 10-2 \mathrm{~g}$ & Autoclaving & $5.20 \cdot 10-2 \mathrm{kWh}$ \\
\hline $\mathrm{Na} 2 \mathrm{MoO} 4 \cdot 2 \mathrm{H} 2 \mathrm{O}$ & $1.57 \cdot 10-3 \mathrm{~g}$ & \multicolumn{2}{|c|}{ Subsystem 2. Preparation of the culture medium } \\
\hline $\mathrm{CuSO} 4 \cdot 5 \mathrm{H} 2 \mathrm{O}$ & $1.63 \cdot 10-4 \mathrm{~g}$ & Ultrapure water system & $0.52 \mathrm{kWh}$ \\
\hline $\mathrm{Co}(\mathrm{NO} 3) 2 \cdot 6 \mathrm{H} 2 \mathrm{O}$ & $1.90 \cdot 10-4 \mathrm{~g}$ & Stirring & $0.11 \mathrm{kWh}$ \\
\hline NH4NO3 & $1.30 \mathrm{~g}$ & Autoclaving & $0.17 \mathrm{kWh}$ \\
\hline $\mathrm{C} 12 \mathrm{H} 22 \mathrm{O} 11$ & $296.66 \mathrm{~g}$ & \multicolumn{2}{|c|}{ Subsystem 3. Cultivation of the inoculums } \\
\hline $\mathrm{HCl}$ & $2.67 \cdot 10-3 \mathrm{ml}$ & Lighting & $4.03 \mathrm{kWh}$ \\
\hline Laboratory glassware & $12.59 \mathrm{~g}$ & Stirring & $6.05 \mathrm{kWh}$ \\
\hline Glass amber bottles & $1.61 \cdot 10-2 \mathrm{~g}$ & \multicolumn{2}{|c|}{ Subsystem 4. Cultivation of the moss } \\
\hline Laboratory plastic ware & $157.05 \mathrm{~g}$ & Reactor tower & $47.23 \mathrm{kWh}$ \\
\hline Stir bars & $2.12 \cdot 10-4 \mathrm{~g}$ & Refrigerated bath & $139.30 \mathrm{kWh}$ \\
\hline Caps & $1.10 \mathrm{~g}$ & Air blowing & $2.99 \mathrm{kWh}$ \\
\hline Crêpe paper & $1.00 \mathrm{~g}$ & Lighting in photobioreactor & $72.58 \mathrm{kWh}$ \\
\hline \multicolumn{2}{|c|}{ Subsystem 3. Cultivation of the inoculum } & \multicolumn{2}{|c|}{ Subsystem 5. Washing and devitalisation of the moss } \\
\hline Laboratory glassware & $0.15 \mathrm{~g}$ & Ultrapure water system & $1.84 \mathrm{kWh}$ \\
\hline Laboratory plastic ware & $17.41 \mathrm{~g}$ & Stirring & $8.00 \cdot 10-2 \mathrm{kWh}$ \\
\hline Rubber caps & $5.64 \cdot 10-3 \mathrm{~g}$ & Drying & $10.91 \mathrm{kWh}$ \\
\hline Stainless steel & $6.88 \cdot 10-3 \mathrm{~g}$ & & \\
\hline Polypropylene caps & $1.99 \cdot 10-3 \mathrm{~g}$ & Transpo & \\
\hline Crêpe paper & $0.55 \mathrm{~g}$ & \multicolumn{2}{|c|}{ Subsystem 2. Preparation of the culture medium } \\
\hline Fabric & $0.11 \mathrm{~g}$ & Lorry, 16-32 t, EURO 4 & $6.42 \mathrm{~kg} \cdot \mathrm{km}$ \\
\hline Nitrile gloves & $13.14 \mathrm{~g}$ & & \\
\hline Aluminium foil & $77.50 \mathrm{~g}$ & & \\
\hline Parafilm & $3.12 \mathrm{~g}$ & & \\
\hline \multicolumn{4}{|c|}{ Outputs to technosphere } \\
\hline \multicolumn{2}{|c|}{ Liquid waste to treatment } & \multicolumn{2}{|c|}{ Liquid waste to treatment } \\
\hline \multicolumn{2}{|c|}{ Subsystem 1. Reactor cleaning } & Subsystem 4. Cultivat & the moss \\
\hline Cleaning agent & 80.021 & Culture medium & 11.891 \\
\hline Subsystem 3. Cultiv & the inoculum & Subsystem 5. Washing and de & sation of the moss \\
\hline Culture medium & 1.001 & Water & 41.641 \\
\hline
\end{tabular}




\begin{tabular}{|c|c|c|c|}
\hline \multicolumn{4}{|c|}{ Outputs to environment } \\
\hline Air emissions & & Water emissions & \\
\hline \multicolumn{2}{|c|}{ Subsystem 4. Cultivation of the moss } & \multicolumn{2}{|c|}{ Subsystem 5. Washing and devitalisation of the moss } \\
\hline Air (excluding CO2) & $76.29 \mathrm{~m} 3$ & EDTA & $32.55 \mathrm{~g}$ \\
\hline $\mathrm{CO} 2$ & $1.47 \mathrm{~m} 3$ & & \\
\hline
\end{tabular}

\section{$2.4 \quad$ Life cycle impact assessment (LCIA)}

The analysis of the midpoint environmental impacts was performed by using ReCiPe (Goedkoop et al. 2009). The impact categories considered according to the ReCiPe methodology were: climate change (CC), ozone depletion (OD), terrestrial acidification (TA), freshwater eutrophication (FE), marine eutrophication (ME), human toxicity (HT), photochemical oxidant formation (POF), terrestrial ecotoxicity (TET), freshwater ecotoxicity (FET) and marine ecotoxicity (MET). SimaPro version 8 was the software selected to perform the LCA calculations (http://www.pre-sustainability.com/simapro).

\section{Results and discussion \\ $3.1 \quad$ Impact categories}

Figure 3 shows the relative contributions per subsystem to each impact category. Subsystem 4, related to the cultivation of moss in photobioreactor, was identified as the most relevant stage in terms of environmental burdens, representing between $78.9 \%$ and $91.1 \%$ of the total impact for ME and HT, respectively. Regarding the other subsystems, reactor cleaning (Subsystem 1) and preparation of culture medium (Subsystem 2) were identified as the least significant contributors. The former led to around $7.4 \%$ in $\mathrm{ME}$ while the highest contribution for Subsystem 2 was $1.4 \%$ in POF category. Regarding Subsystem 3, the highest relative contribution was observed in OD category (around 7.3\%) where laboratory ware and electricity production led to $50 \%$ each. Finally, Subsystem 5 caused $5 \%$ of the total impact to each category, except for ME, in which this subsystem contributed $9.6 \%$ to the total impact.

The issues comprised in each subsystem were analysed separately and energy was found to be the main contributor to all environmental categories (Figure 4). More specifically, energy required for the refrigerated bath $(139.30 \mathrm{kWh}$ per batch) represented more than $50 \%$ of the total energy required in the production system. Consequently, the energy used in the refrigerated bath could be considered as the hotspot of the studied process, and therefore, temperature set at $10^{\circ} \mathrm{C}$ inside the bath is considered susceptible of revision. A similar profile was obtained when the process for eicosapentaenoic acid (EPA) extraction from microalgae was analysed (PérezLópez et al., 2013). The authors demonstrated that the cultivation of the microalgae Phaetodactylum tricornutum in photobioreactors contributed more than $80 \%$ to the total impact, which is in accordance with the outcomes from this study. Regarding the importance of energy use, it was underlined that energy is the main hotspot in the microalgae cultivation process, external lighting being the main source since no refrigeration system was used in the microalgal photobioreactor system ( Pérez-López, Feijoo, \& Moreira, 2014a; Pérez-López et al. 2014c). Additionally, the importance of energy use in artificially illuminated systems was determined for the cultivation of marine sponges in aquariums, in which case the aquarium lighting accounted for three fourths of the total electricity requirements (PérezLópez et al. 2014e).

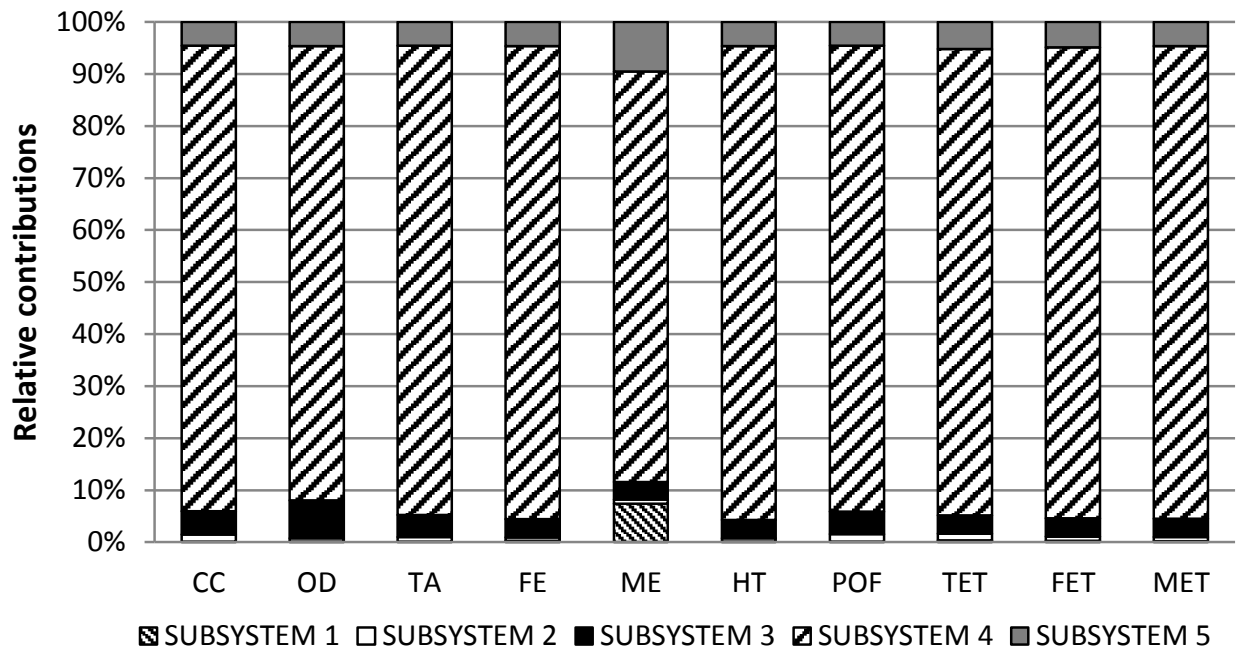

Figure 3. Relative contributions per subsystem to each impact category (in \%).

In CC impact category, energy led to $88.07 \mathrm{~kg}$ $\mathrm{CO}_{2}$ eq per $\mathrm{FU}$ (97\% of the total value of $90.44 \mathrm{~kg}$ $\mathrm{CO}_{2}$ eq per $\mathrm{FU}$ ), where the refrigerated bath used in
Subsystem 4 contributed with $49 \%$. The analysis of the Spanish energetic profile shows the dependence on fossil fuels, specifically, electricity based on coal 
contributes up to $15 \%$. In this case, the extraction of hard coal from mine was the main responsible of carbon dioxide emissions.

Regarding OD, electricity represented more than $95 \%$ of the total impact $\left(7.31 \cdot 10^{-6} \mathrm{~kg} \mathrm{CFC}-11\right.$ eq per batch) while laboratory ware only accounted for a minimal contribution: $4 \%$ (Figure 4). Emissions of
Halon 1211 to air through natural gas transportation were responsible for most of the OD impact associated to energy. Regarding laboratory ware, most of the impact corresponded to the production of aluminium foil used in Subsystem 3. In this case, Halon 1301 was emitted to the atmosphere associated with aluminium foil production.

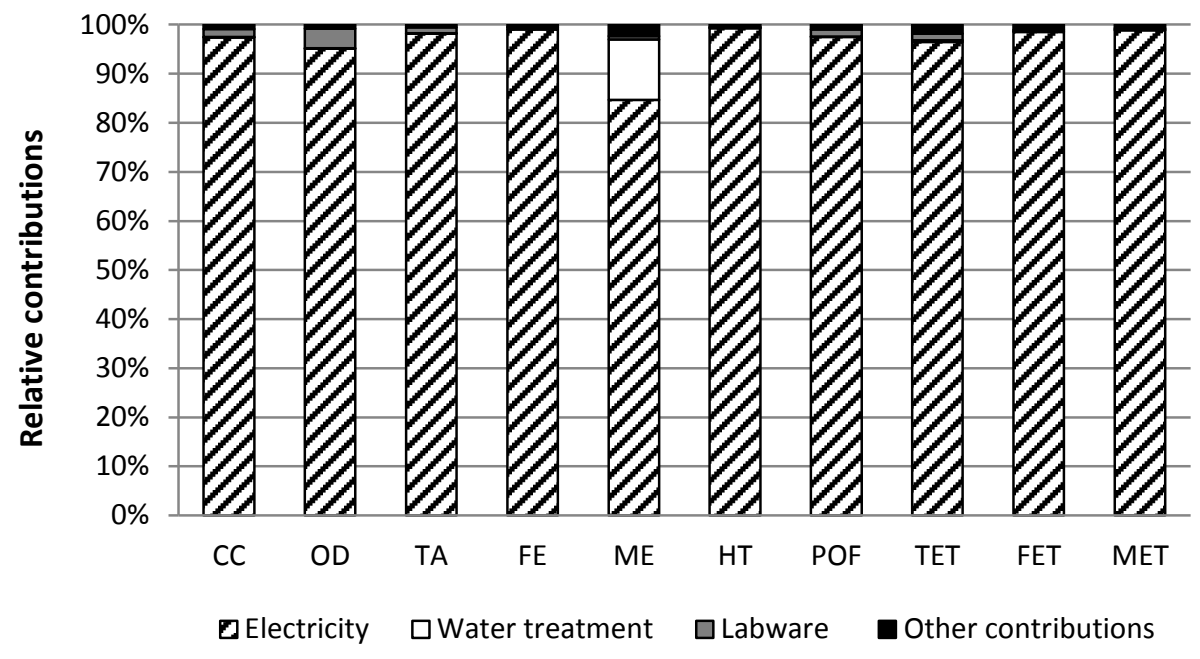

Figure 4. Contributions from the different input parameters to each impact category (in \%).

The production of electricity was the main contributor (98\%) to TA associated impact: $0.65 \mathrm{~kg}$ $\mathrm{SO}_{2}$ eq per FU (Figure 4). Most of energy use corresponded to the use of refrigerated bath in Subsystem 4. In this case, laboratory ware production only accounted for $1 \%$ of the environmental burdens. The rationale behind $\mathrm{SO}_{2}$ emissions to air is the production of electricity in coal based power plants.

Subsystem 4 led to $91 \%$ of the FE total impact $\left(4.18 \cdot 10^{-2} \mathrm{~kg} \mathrm{P}\right.$ eq per FU), followed by Subsystems 5 and 3. On the other hand, Subsystems 1 and 2 presented negligible contributions (Figure 3). Energy use accounted for $99 \%$ of the total burdens (Figure 4). The main cause for this impact was associated to the phosphate emitted to water during the extraction of lignite and hard coal from mines. ME showed relevant differences in the other categories. The category was the least influenced by energy use, although it represented around $85 \%$ of the total impact. Emission of nitrogen oxides to air in hard coal burning had significant relevance in the impact associated to electricity. In this case, the treatment of liquid emissions in a WWTP accounted for $12 \%$ of the total impact. Most liquid emissions are generated in Subsystem 1, due to the significant volume of water (80 1) used for reactor cleaning and consequently, around $50 \%$ of the impact associated to further treatment of wastewater corresponded to Subsystem 1. Nitrogen emissions during WWTP construction were the main factor responsible for the impact. Similarly to CC, TA and FE, the categories POF, HT, FET and MET showed significant impacts due to the contribution of emissions from the production of energy which was used during the process (around 99\% of the total impact). Emissions of Mn to water and NOx to air led to high impacts in HT and POF and Ni emitted to water mainly contributed to FET and MET impacts.

Although TET showed a similar behaviour with energy as the main hotspot, not only hard coal, but also oil and photovoltaic energy led to TET associated impacts. In this case, $\mathrm{Ag}$ and $\mathrm{V}$ emissions released to air contributed to photovoltaic and oil energy associated impacts, respectively.

\subsection{Improvement scenarios}

Energy use was identified as the main hotspot in the moss production system. Particularly, the supply of energy by non-renewable sources such as hard coal appeared to be the least recommendable options under an environmental perspective. Therefore, different scenarios were proposed with the aim of studying alternative energy sources and reducing energy requirements. The base scenario, which corresponds to the real case study, was named as Scenario A. Scenario B corresponded to the combination of two energy sources: electricity from the grid (50\%) and photovoltaic energy $(50 \%)$, considering the latter as an environment-friendly alternative. Scenario C represented the use of photovoltaic energy as the only source for the production of devitalised moss. Finally, for Scenario $\mathrm{D}$ was assumed that the reactor would be located in a room with constant temperature $\left(25^{\circ} \mathrm{C}\right)$, and therefore the refrigerated bath and the external tower would not be necessary to control temperature. In this situation, a smaller refrigerated bath would be used only for the condenser and the energy use was assumed to be $10 \%$ of the existing bath based on the relation between the water flow to the condenser and to the cooling jacket. Additionally, the energy used by the external tower could be reduced to $20 \%$ of the 
current demand since it would be only used to measure conventional parameters, such as $\mathrm{pH}$. Taking into account these considerations, the total energy use would be reduced by $60 \%$. The four scenarios are represented in Figure 5, where impacts related to Scenario A (real case) are defined as $100 \%$ and the other scenarios are calculated from the base scenario.

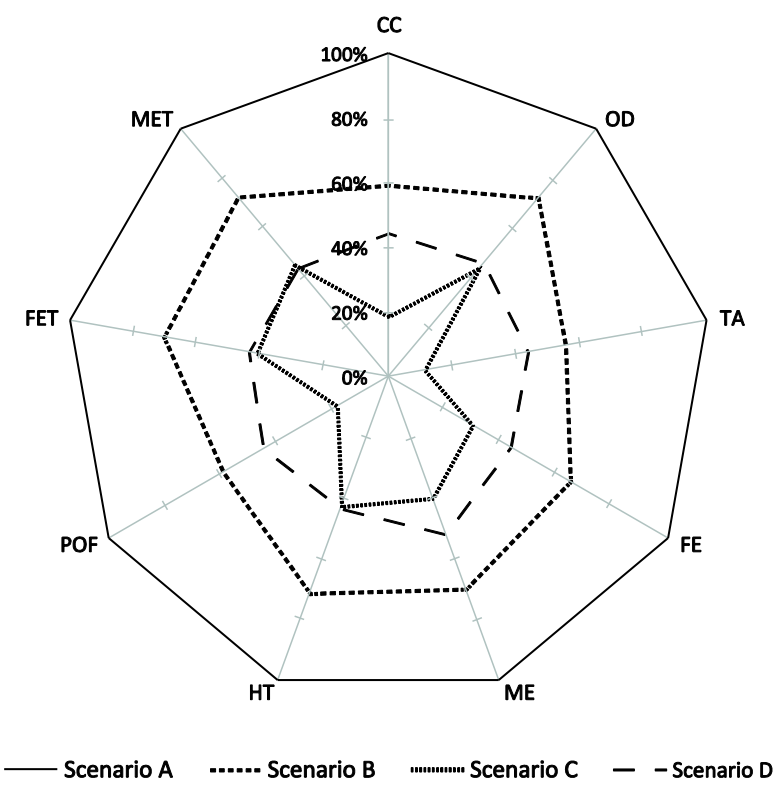

Figure 5. Comparison among scenarios proposed for moss cultivation (in \%), excluding terrestrial ecotoxicity.

The outcomes showed that the environmental profile improved for all alternative scenarios assessed, except for TET, which was excluded from Figure 5 for a better display of the results. At a glance, Scenario A could be classified as the worst option, whereas Scenario C showed the lowest environmental burdens, except for TET category (Table 3). These results are in accordance with Pérez-López et al. (2014a), who recommended the use of renewable sources to decrease the impacts associated with the use of photobioreactors.

Table 3. Results of alternative scenarios for the 10 impact categories assessed.

\begin{tabular}{||l|l|l|l|l|l||}
\hline Impact category & \multicolumn{1}{c|}{ Unit } & Scenario A & Scenario B & Scenario C & Scenario D \\
\hline CC & $\mathrm{kg} \mathrm{CO}_{2}$ eq & 90.44 & 53.69 & 16.93 & 40.25 \\
\hline OD & $\mathrm{kg} \mathrm{CFC}-11$ eq & $7.31 \cdot 10^{-6}$ & $5.28 \cdot 10^{-6}$ & $3.25 \cdot 10^{-6}$ & $3.35 \cdot 10^{-6}$ \\
\hline TA & $\mathrm{kg} \mathrm{SO}_{2}$ eq & 0.65 & 0.36 & $7.51 \cdot 10^{-2}$ & 0.29 \\
\hline FE & $\mathrm{kg} \mathrm{P} \mathrm{eq}$ & $4.18 \cdot 10^{-2}$ & $2.72 \cdot 10^{-2}$ & $1.26 \cdot 10^{-2}$ & $1.82 \cdot 10^{-2}$ \\
\hline ME & $\mathrm{kg} \mathrm{N} \mathrm{eq}$ & $2.24 \cdot 10^{-2}$ & $1.57 \cdot 10^{-2}$ & $9.03 \cdot 10^{-3}$ & $1.16 \cdot 10^{-2}$ \\
\hline HT & $\mathrm{kg} \mathrm{1,4-DB} \mathrm{eq}$ & 46.24 & 33.05 & 19.87 & 20.09 \\
\hline POF & $\mathrm{kg} \mathrm{NMVOC}$ & 0.33 & 0.20 & $6.16 \cdot 10^{-2}$ & 0.15 \\
\hline TET & $\mathrm{kg} \mathrm{1,4-DB} \mathrm{eq}$ & $5.31 \cdot 10^{-3}$ & $1.69 \cdot 10^{-2}$ & $2.84 \cdot 10^{-2}$ & $2.39 \cdot 10^{-3}$ \\
\hline FET & $\mathrm{kg} \mathrm{1,4-DB} \mathrm{eq}$ & 0.94 & 0.67 & 0.39 & 0.41 \\
\hline MET & $\mathrm{kg} \mathrm{1,4-DB} \mathrm{eq}$ & 0.96 & 0.70 & 0.44 & 0.42 \\
\hline
\end{tabular}

After Scenario A, Scenario B showed the highest impacts, presenting larger burdens than Scenarios C and $\mathrm{D}$ in all the evaluated categories, except for TET category. Regarding Scenario D, this option resulted to be the best option together with Scenario C for impact categories such as FET, MET, OD and HT, whereas it was the second best option for CC, TA, FE, ME and POF. When it comes to TET, Scenario D reduced the impact when compared to the baseline scenario whereas Scenarios B and C presented the largest impacts due to the use of photovoltaic energy. $\mathrm{CC}$ impact associated with Scenario A $(90.44 \mathrm{~kg} \mathrm{CO} 2$ eq per FU) was reduced up to $81 \%$ for Scenario C. These results proved that photovoltaic energy is considerably more beneficial than the production of electricity from the grid when considering the avoided $\mathrm{CO}_{2}$ emissions to the atmosphere. Moreover, in terms of $\mathrm{CO}_{2}$ emissions, Scenario $\mathrm{D}$ with lower energy demand showed better results (56\% of reduction) than Scenario B, which combined the use of energy from the grid and photovoltaic electricity at the current use of energy (41\% of reduction). Scenario A showed the highest OD impact: $7.31 \cdot 10^{-6} \mathrm{CFC}-11$ eq per FU, which was reduced by $\sim 28 \%, 54 \%$ and $56 \%$ for Scenarios B, D and C, respectively. The option of combining two different energy sources led to higher burdens whereas the other two alternatives showed similar results. In this case, photovoltaic energy as the only alternative source and energy reduction appeared to be the most beneficial options for the environment.

TA showed a similar profile to $\mathrm{CC}$, where Scenario $\mathrm{D}$ was more recommendable than $\mathrm{B}$, presenting reductions of $56 \%$ and $44 \%$, respectively whereas Scenario C reduced the impact by $90 \%$. The production of $1 \mathrm{kWh}$ of photovoltaic energy led to 
$2.22 \cdot 10^{-4} \mathrm{~kg} \mathrm{SO}_{2}$ eq per FU whereas $1 \mathrm{kWh}$ of energy from the grid showed $2.24 \cdot 10^{-3} \mathrm{~kg} \mathrm{SO}$ eq per FU.

When it comes to $\mathrm{FE}$ and $\mathrm{ME}$, Scenario $\mathrm{C}$ showed the lowest impacts, followed by D and B. If only renewable sources were used (Scenario $\mathrm{C}$ ), environmental burdens would be reduced by $70 \%$ and $60 \%$ for $\mathrm{FE}$ and $\mathrm{ME}$, respectively. POF outcomes were comparable to $\mathrm{CC}, \mathrm{TA}, \mathrm{FE}$ and $\mathrm{ME}$ profiles: Scenario $\mathrm{C}$ showing the best results with $82 \%$ of reduction in comparison with Scenario A, followed by $\mathrm{D}$ and $\mathrm{B}$, with reductions around $56 \%$ and $41 \%$, respectively. As observed in Figure 5, FET, MET and HT showed a similar profile to OD category, reductions being around $30 \%$ for Scenario B and 55$58 \%$ for Scenarios C and D. Therefore, in terms of aquatic ecotoxicity and human toxicity, the reduction of energy requirements is as suitable as the use of photovoltaic energy as the only source. Unlike the rest of impact categories, Scenarios B and C showed higher impacts than the base scenario in TET (Table 3). In fact, TET is the only category where photovoltaic energy led to much higher environmental burdens than the energy from the grid: $9.88 \cdot 10^{-5}$ vs $1.79 \cdot 10^{-5} \mathrm{~kg} 1,4-\mathrm{DCB}$ eq per $\mathrm{kWh}$ produced. Although in both cases silver emissions released to air were responsible for the impact, photovoltaic energy emitted higher concentrations than energy used from the grid. On the other hand, TET was reduced by $55 \%$ when Scenario D was compared with Scenario A, with the reduction of energy as the best alternative to take in this specific case. Nevertheless, it should be noted that the damaging effect of photovoltaic energy was only observed for TET while this source presented the lowest impacts for the rest of categories, turning Scenario $\mathrm{C}$ into the most beneficial alternative despite the effect observed in TET.

\subsection{Sensitivity analysis}

The system under study was located in Spain and consequently, the Spanish energy profile was considered for the calculations. However, noticing the relevant contribution of energy use in the total impact, the alternative of taking the energy from a different country was considered interesting for the environmental assessment. For this reason, the LCA study was performed considering the process for average electricity production in Europe and relevant differences were observed in the total impact for the assessed categories. Considering the European mix included in Ecoinvent, the process showed environmental burdens approximately 3 times higher than in the baseline scenario for FE, MET and FET with impacts per FU of $0.14 \mathrm{~kg} \mathrm{P}$ eq, $2.45 \mathrm{~kg} \mathrm{1,4-}$ DCB eq and $2.42 \mathrm{~kg} \mathrm{1,4-DCB}$ eq, respectively. The reason behind this is that the typical average European mix relies more on fossil sources than the updated Spanish profile, leading to higher factors per $\mathrm{kWh}$ produced, such as $0.56 \mathrm{~kg} \mathrm{CO}_{2}$ eq instead of $0.31 \mathrm{~kg} \mathrm{CO}_{2}$ eq calculated for Spain. Even so, when it comes to comparing the share of each subsystem in the total impact, Subsystem 4 was again the main contributor, with similar contributions to those observed for the baseline scenario. Additionally, the importance of energy use was underlined as the main hotspot in the assessment, showing similar shares to the Spanish profile.

Regarding the improvement scenarios, the average European mix was considered for Scenarios A, B and D, whereas the single use of photovoltaic energy was considered for Scenario C. In general, the same conclusions were obtained from the analysis, where Scenario C presented the best performance, while Scenario A was the least recommendable option (Figure 6). However, it should be highlighted that the high impact associated with the European energy production led the use of photovoltaic energy (Scenario C) to perform better than Scenario D in all categories, except for TET, while using Spanish energy mix both Scenarios showed similar reductions in FET, MET, OD and HT.

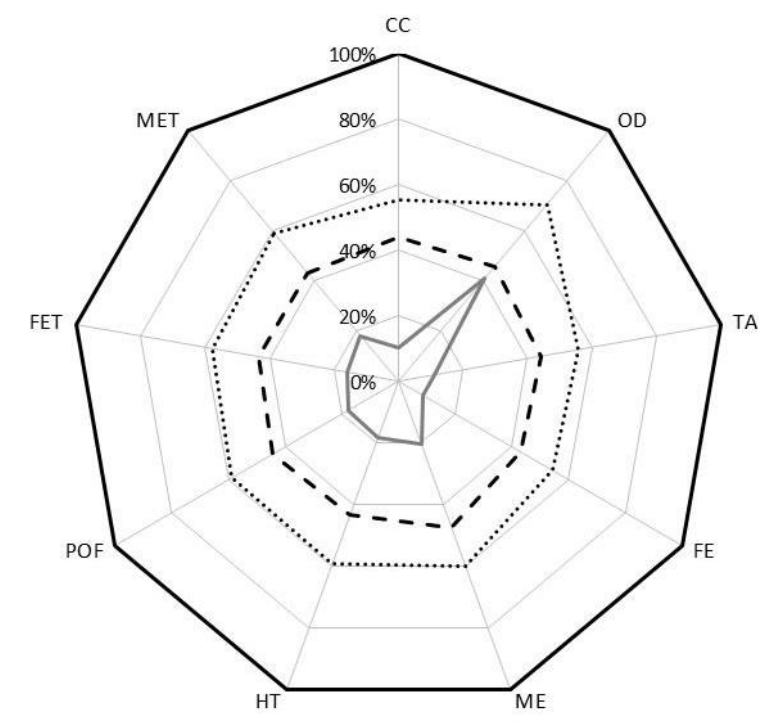

- Scenario A ….. Scenario B - Scenario C - - Scenario D
Figure 6. Comparison among scenarios (in \%) using the European energy mix and excluding terrestrial ecotoxicity. 


\section{Conclusions}

The main objective of this research paper was to perform a life cycle assessment of the production of dry moss, which is used as air quality biosensor that can accumulate atmospheric pollutants. The production process was assessed and inventoried for 1 batch of production in a 151 glass photobioreactor. The system was divided into 5 subsystems and the key environmental burdens were identified for each subsystem and for the global process. The significant use of energy in Subsystem 4, which corresponded to the cultivation of moss in the photobioreactor, led to the highest impact in all categories evaluated. Although the reactor was continuously illuminated, the highest consumption of energy is associated to an external refrigerated bath, used for the condenser and for maintaining constant temperature. Considering this point as the hotspot of the process, improvement alternatives were suggested, based on the total energy required but also in the energy source.

Summing up the outcomes from the environmental assessment, the lowest impacts in the different impact categories were attained when actions are taken to reduce the energy consumption and only photovoltaic energy is used. Moreover, the partial implementation of photovoltaic energy may be a compromise solution with acceptable reduction of environmental impacts and easier implementation in the process.

\section{Acknowledgements}

This research was supported by the European Commission through FP7 Project MossClone (ENV.2011.3.1.9-1, project number: 282952). The authors from the Department of Chemical Engineering (USC) belong to the Galician Competitive Research Group GRC 2013-032, programme co-funded by FEDER.

\section{References}

Aboal, J. R., Couto, J. A., Fernández, J. A., \& Carballeira, A. (2006). Definition and number of subsamples for using mosses as biomonitors of airborne trace elements. Archives of Environmental Contamination and Toxicology, 50, 88-96. http://dx.doi.org/10.1007/ s00244-005-7006-9

Adamo, P., Giordano, S., Sforza, A., \& Bargagli, R. (2011). Implementation of airborne trace element monitoring with devitalised transplants of Hypnum cupressiforme Hedw.: Assessment of temporal trends and element contribution by vehicular traffic in Naples city. Environmental Pollution, 159, 1620-1628. http://dx.doi.org/10.1016/i.envpol.2011.02.047

Althaus, H. J., Chudacoff, M., Hischier, R., Jungbluth, N., Osses, M., \& Primas A. (2007). Life cycle inventories of chemicals. Ecoinvent report no. 8. Dübendorf, $\mathrm{CH}$ : Swiss Centre for Life Cycle Assessment.

Ares, A., Aboal, J. R., Carballeira, A., Giordano, S., Adamo, P., \& Fernández J. A. (2012). Moss bag biomonitoring: A methodological review. Science of
The Total Environment, 432, 143-158. http://dx.doi.org/ 10.1016/j.scitotenv.2012.05.087

Beike, A., Spagnuolo, V., Lüth, V., Steinhart, F., RamosGómez, J., Krebs, M., Adamo, P., Rey-Asensio, A., Angel Fernández, J., Giordano, S., Decker, E., \& Reski, R. (2014). Clonal in vitro propagation of peat mosses (Sphagnum L.) as novel green resources for basic and applied research. Plant Cell, Tissue and Organ Culture (PCTOC), pp. 1-13. http://dx.doi.org/10.1007/s11240014-0658-2

Cao, T., Wang, M., An, L., Yu, Y., Lou, Y., Guo, S., Zuo, B., Liu, Y., Wu, J., Cao, Y., \& Zhu, Z. (2009). Air quality for metals and sulfur in Shanghai, China, determined with moss bags. Environmental Pollution, 157, 1270-1278. http://dx.doi.org/10.1016/j.envpol. 2008.11.051

Clara, M., Windhofer, G., Weilgony, P., Gans, O., Denner, M., Chovanec, A., \& Zessner, M. (2012). Identification of relevant micropollutants in Austrian municipal wastewater and their behaviour during wastewater treatment. Chemosphere, 87, 1265-1272. http://dx.doi.org/10.1016/j.chemosphere.2012.01.033

Decker, E. L. \& Reski, R. (2004). The moss bioreactor. Current Opinion in Plant Biology, 7, 166-170. http://dx.doi.org/10.1016/j.pbi.2004.01.002

Decker, E. L. \& Reski, R. (2007). Moss bioreactors producing improved biopharmaceuticals. Current Opinion in Biotechnology, 18, 393-398. http://dx.doi.org/10.1016/j.copbio.2007.07.012

Doka, G. (2007). Life cycle inventories of waste treatment services. Ecoinvent report No. 13, Dübendorf, $\mathrm{CH}$ : Swiss Centre for Life Cycle Inventories.

Dones, R., Bauer, C., Bolliger, R., Burger, B., Faist Emmenegger, M., Frischknecht, R., Heck, T., Jungbluth, N., Röder, A., \& Tuchschmid, M. (2007). Life cycle inventories of energy systems: Results for current systems in Switzerland and other UCTE countries. Ecoinvent report no. 5. Dübendorf, $\mathrm{CH}$ : Swiss Centre for Life Cycle Assessment.

European Commission. (2004). Directive 2004/107/EC of the European Parliament and of the council of 15 December 2004 relating to arsenic, cadmium, mercury, nickel and polycyclic aromatic hydrocarbons in ambient air. Off. J. Eur. Union, 23, 1e16.

Ecoinvent. (2007). Swiss Centre for Life Cycle Inventories (Ecoinvent Centre). Ecoinvent Database. Dübendorf, CH: Ecoinvent Centre. 2004 and 2007.

Fabure, J., Meyer, C., Denayer, F., Gaudry, A., Gilbert, D., \& Bernard, N. (2010). Accumulation capacities of particulate matter in an acrocarpous and a pleurocarpous moss exposed at three differently polluted sites (industrial, urban and rural). Water, Air \& Soil Pollution, 212, 205-217. http://dx.doi.org/10.1007/ s11270-010-0333-0

Fernández, J. A., Ares, A., Rey-Asensio, A., Carballeira, A., \& Aboal, J. (2009). Effect of growth on active biomonitoring with terrestrial mosses. Journal of Atmospheric Chemistry, 63, 1-11. http://dx.doi.org/ 10.1007/s10874-010-9152-3

Ferreira, A. B., Santos, J. O., Souza, S. O., Júnior, W. N. S., \& Alves J. D. P. H. (2012). Use of passive biomonitoring to evaluate the environmental impact of emissions from cement industries in Sergipe State, northeast Brazil. Microchemical Journal, 103, 15-20. http://dx.doi.org/10.1016/j.microc.2011.12.008

Garrido, A., Jiménez-Guerrero, P., \& Ratola, N. (2014). Levels, trends and health concerns of atmospheric PAHs in Europe. Atmospheric Environment, 99, 474-484. http://dx.doi.org/10.1016/j.atmosenv.2014.10.011 
Gerdol, R., Marchesini, R., Iacumin, P., \& Brancaleoni, L. (2014). Monitoring temporal trends of air pollution in an urban area using mosses and lichens as biomonitors. Chemosphere, 108, 388-395. http://dx.doi.org/10.1016/ j.chemosphere.2014.02.035

Goedkoop, M., Heijungs, R., Huijbregts, M., De Schryver, A., Struijs, J., \& van Zelm, R. (2009). ReCiPe 2008 - A life cycle impact assessment method which comprises harmonised category indicators at the midpoint and the endpoint level. The Netherlands: Ministry of Housing, Spatial Planning and Environment (VROM).

Harmens, H., Foan, L., Simon, V., \& Mills, G. (2013). Terrestrial mosses as biomonitors of atmospheric POPs pollution: A review. Environmental Pollution, 173, 245254. http://dx.doi.org/10.1016/j.envpol.2012.10.005

Hischier, R. (2007). Life cycle inventories of packaging and graphical papers. Ecoinvent report no. 11. Dübendorf, $\mathrm{CH}$ : Swiss Centre for Life Cycle Inventories.

Hohe, A. \& Reski, R. (2002). Optimisation of a bioreactor culture of the moss Physcomitrella patens for mass production of protoplasts. Plant Science, 163, 69-74. http://dx.doi.org/10.1016/S0168-9452(02)00059-6

Hohe, A. \& Reski, R. (2005). Control of growth and differentiation of bioreactor cultures of Physcomitrella by environmental parameters. Plant Cell, Tissue and Organ Culture, 81, 307-311. http://dx.doi.org/10.1007/ s11240-004-6656-Z

International Organisation for Standardization (ISO). (2006). ISO 14040: Environmental management - life cycle assessment - principles and framework. Geneva: Author.

Kampa, M. \& Castanas, E. (2008). Human health effects of air pollution. Environmental Pollution, 151, 362-367. http://dx.doi.org/10.1016/j.envpol.2007.06.012

Lucumi, A. \& Posten C. (2006). Establishment of long-term perfusion cultures of recombinant moss in a pilot tubular photobioreactor. Process Biochemistry, 41, 2180-2187. http://dx.doi.org/10.1016/j.procbio. $\underline{2006.06 .017}$

Lucumi, A., Posten, C., \& Pons, M. N. (2005). Image analysis supported moss cell disruption in photobioreactors. Plant Biology, 7, 276-282. http://dx.doi.org/ 10.1055/s-2005-865638

Pérez-López, P., Feijoo, G., \& Moreira, M. T. (2014a). Aplicación de la metodología de Análisis de Ciclo de Vida para la producción sostenible de ingredientes activos a partir de organismos marinos. Revista Alimentaria, 455, 40-46.

Pérez-López, P., González-García, S., Allewaert, C., Verween, A., Murray, P., Feijoo, G., \& Moreira M. T. (2014b). Environmental evaluation of eicosapentaenoic acid production by Phaeodactylum tricornutum. Science of The Total Environment, 466-467, 991-1002. http://dx.doi.org/10.1016/j.scitotenv.2013.07.105

Pérez-López, P., González-García, S., Allewaert, C., Verween, A., Vyverman, W., Murray, P., Feijoo, G., \& Moreira, M. T. (2013). Environmental assessment of the sustainable production of polyunsaturated fatty acids by Phaeodactylum tricornutum. In: 9th European Congress of Chemical Engineering \& 2nd European Congress of Applied Biotechnology, The Netherlands.

Pérez-López, P., González-García, S., Jeffryes, C., Agathos, S. N., McHugh, E., Walsh, D., Murray, P., Moane, S., Feijoo, G., \& Moreira, M. T. (2014c). Life cycle assessment of the production of the red antioxidant carotenoid astaxanthin by microalgae: from lab to pilot scale. Journal of Cleaner Production, 64, 332-344. http://dx.doi.org/10.1016/j.jclepro.2013.07.011

Pérez-López, P., González-García, S., Ulloa, R. G., Sineiro, J., Feijoo, G., \& Moreira, M. T. (2014d). Life cycle assessment of the production of bioactive compounds from Tetraselmis suecica at pilot scale. Journal of Cleaner Production, 64, 323-331. http://dx.doi.org/ 10.1016/j.jclepro.2013.07.028

Pérez-López, P., Ternon, E., González-García, S., GentaJouve, G., Feijoo, G., Thomas, O. P., \& Moreira, M. T. (2014e). Environmental solutions for the sustainable production of bioactive natural products from the marine sponge Crambe crambe. Science of the Total Environment, 475, 71-82. http://dx.doi.org/10.1016/ i.scitotenv.2013.12.068

Perner-Nochta, I., Lucumi, A., \& Posten, C. (2007). Photoautotrophic cell and tissue culture in a tubular photobioreactor. Engineering in Life Sciences, 7, 127135. http://dx.doi.org/10.1002/elsc.200620178

RedElectrica. (2013). Red Eléctrica de España. El sistema eléctrico español [In Spanish].

Reski, R. \& Abel, W. O. (1985). Induction of budding on chloronemata and caulonemata of the moss, Physcomitrella patens, using isopentenyladenine. Planta, 165, 354-358. http://dx.doi.org/10.1007/ BF00392232

Rühling, A. \& Tyler, G. (1968). An ecological approach to the lead problem. Botaniska Notiser, 122, 248-342.

Schröder, W., Pesch, R., Englert, C., Harmens, H., Suchara, I., Zechmeister, H. G., Thöni, L., Maňkovská, B., Jeran, Z., Grodzinska, K., \& Alber, R. (2008). Metal accumulation in mosses across national boundaries: Uncovering and ranking causes of spatial variation. Environmental Pollution, 151, 377-388.

Schween, G., Hohe, A., Koprivova, A., \& Reski, R. (2003). Effects of nutrients, cell density and culture techniques on protoplast regeneration and early protonema development in a moss, Physcomitrella patens. Journal of Plant Physiology, 160, 209-212. http://dx.doi.org/ $\underline{10.1078 / 0176-1617-00855}$

Spielmann, M., Bauer, C., Dones, R., \& Tuchschmid, M. (2007). Transport Services. Ecoinvent report no. 14. Dübendorf, $\mathrm{CH}$ : Swiss Centre for Life Cycle Inventories.

Steiner, R. \& Frischknecht, R. (2007). Metals processing and compressed air supply. Ecoinvent report No. 23. Dübendorf, $\mathrm{CH}$ : Swiss Centre for Life Cycle Inventories.

Tretiach, M., Adamo, P., Bargagli, R., Baruffo, L., Carletti, L., Crisafulli, P., Giordano, S., Modenesi, P., Orlando, S., \& Pittao E. (2007). Lichen and moss bags as monitoring devices in urban areas. Part I: Influence of exposure on sample vitality. Environmental Pollution, 146, 380-391. $\quad$ http://dx.doi.org/10.1016/j.envpol. 2006.03 .046

Vallero, D. (2014). Air Pollution's Impact on Ecosystems. In: Vallero, D. (Ed.). Fundamentals of Air Pollution (5th Ed.) (Ch. 14). Boston: Academic Press. http://dx.doi.org/10.1016/B978-0-12-401733-7.00014-1

Vuković, G., Aničić Urošević, M., Razumenić, I., Kuzmanoski, M., Pergal, M., Škrivanj, S., \& Popović, A. (2014). Air quality in urban parking garages (PM10, major and trace elements, PAHs): Instrumental measurements vs. active moss biomonitoring. Atmospheric Environment, 85, 31-40. http://dx.doi.org/ 10.1016/j.atmosenv.2013.11.053

Wu, Q., Wang, X., \& Zhou, Q. (2014). Biomonitoring persistent organic pollutants in the atmosphere with mosses: Performance and application. Environment International, 66, 28-37. http://dx.doi.org/10.1016/ j.envint.2013.12.021

Zah, R. \& R. H. (2007). Life cycle inventories of detergents. Ecoinvent report no. 12. Dübendorf, $\mathrm{CH}$ : Swiss Centre for Life Cycle Inventories. 


\section{Naujo biotechnologinio jutiklio, pagrịsto devitalizuotų samanų klonu, vertinimas aplinkosauginio veiksmingumo požiūriu oro kokybei stebėti}

\section{Carolina Alfonsín $\mathbf{1}$, Paula Pérez-López ${ }^{1}$, Ana Isabel Rey-Asensio ${ }^{2}$, Carlos Carballeira $^{3}$, Gumersindo Feijoo ${ }^{1}$ and Maria Teresa Moreira ${ }^{1}$}

${ }^{1}$ Cheminès inžinerijos katedra, Technologiju institutas, Santiago de Compostela universitetas, Santiago de Compostela, Galicija, Ispanija.

${ }^{2}$ BIOVIA Consultor Ambiental, Edificio Emprendia, Campus Vida, 15782 Santiago de Compostela, Galicija, Ispanija.

${ }^{3}$ Ekologijos katedra, Biologijos fakultetas, Santiago de Compostela universitetas, Santiago de Compostela, Galcija, Ispanija.

(gauta 2015 m. kovo mèn.; priimta spaudai 2015 m. kovo mèn.)

Pastaraisiais metais buvo siūloma naudoti samanas kaip galimus biomonitorius oro kokybei stebèti. Tinkamiausią tokių biojutiklių tipą sudaro samanos, užaugintos neužterštose natūraliose buveinèse arba fotobioreaktoriuose. Buvo ịvertinti samanų gamybos ir jų devitalizavimo procesai, siekiant nustatyti procesų etapus, kuriuose daromas didžiausias poveikis aplinkai. Pagrindinis aspektas, kurio poveikis jūrinei eutrofikacijai sudaro nuo 85 proc., o likusioms kategorijoms - iki 95 proc., buvo energijos sąnaudos, ypač susijusios su šaldymo procesu samanų auginimo fazèje. Rezultatai buvo palyginti su ankstesnèmis studijomis, susijusiomis su dumblių gamyba fotobioreaktoriuose. Juose elektros sąnaudos apšvietimui taip pat buvo pagrindinè kritiné problema. Buvo pasiūlyti scenarijai, pagrịsti sumažèjusiu energijos poreikiu ir alternatyvių energijos šaltinių diegimu. Jie parodè geresni aplinkosauginį veiksmingumą negu bazinis scenarijus. Visose tirtose kategorijose, išskyrus sausumos ekotoksiškumą, dèl fotovoltinès energijos naudojimo poveikis aplinkai galètų sumažinti 50 proc., tačiau fotovoltinès energijos naudojimas kartu su tradicine energija lemtų žymiai mažesni veiksmingumo rodikli. Šaldymo sistemos optimizavimo galimybė taip pat lemtų reikšmingus sutaupymus ir būtų laikoma geriausia alternatyva, jei būtų tiriamas sausumos ekotoksiškumas.

Raktiniai žodžiai: oro kokybè, aplinkosauginis vertinimas, būvio ciklo vertinimas (LCA), samany klonavimas, fotobiorektorius. 